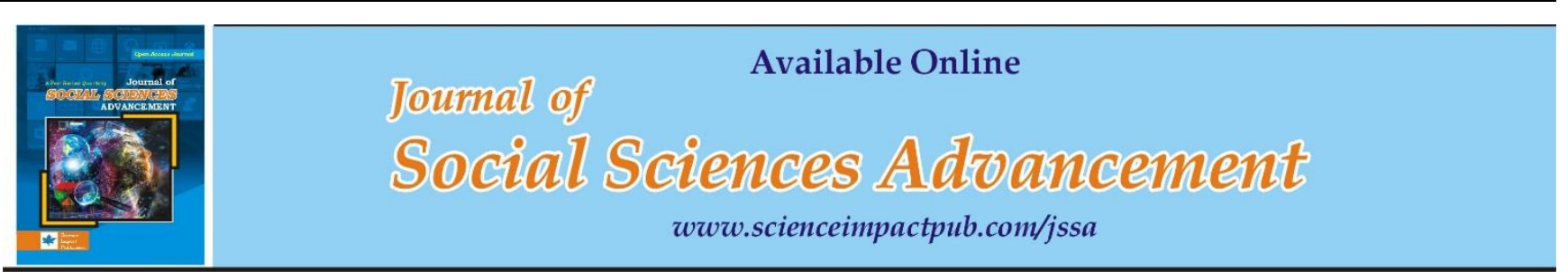

\title{
ANALYSIS OF TEACHER PROFESSIONAL DEVELOPMENT IN TANZANIA: VIEW POINT SCHOOL MANAGEMENT PRACTICE
}

\author{
Rose Sam Mbuli ${ }^{1}$ and Jiajun Zhang ${ }^{1}$ \\ ${ }^{1}$ Faculty of Education, Southwest University, Chongqing, China
}

\begin{abstract}
The study analyse teacher professional development (PD) in Tanzania in view of school management practice in supporting teacher professional development. The present study take school management practice as a factor which can affect teacher professional development. The instruments which are used for the purpose of data collection were interviews, questionnaires, focus group and documentary review. The study examined the prevalence of teacher's initiated management practices such as planning \& scheduling, short term training programs \& seminars, formal mentoring program, meeting held at school level and to encourage teachers on the effective utilization of teachers learning resource. As well the study outcomes recommend the government to increase autonomy to school management to enhance the power to choose specific objective to teacher's professional development.
\end{abstract}

Keywords: Teachers professional development; School management practices; Teacher resources centre; Professional development program; Formal mentoring program; Short term training program and seminars

Corresponding Author: Rose Sam Mbuli, Email:rosemgambuli@gmail.com

(C) The Author(s) 2020.

\section{INTRODUCTION}

Teachers, are considered an important component in the teaching and learning process. They have several responsibilities in educational sphere, not only as teachers to transfer knowledge and skill but also as monitors who boost the potentials in teaching and learning process for better educational results (Abd-Kadir, 2013). It is also meant that that teachers have heavy tasks and responsibilities in respect of achievement of educational goals where they are required to not only master the subject area being taught but are also required displaying a personality, suitable for acting as a role model for students (Mkumbo, 2012). The complex tasks and responsibilities of achieving educational goals relate to teachers' education, skill and knowledge, so that well organized form of knowledge will boost teachers daily routine in fulfilling educational goals (Regan et al, 2016).

Standard educational system depends on the quality of its teachers. So there must be a well-organized system for the encouragement of teachers to develop themselves and to prove a potential teacher with full of knowledge and competence. Teachers' competence should be established through integrated and logical ways (Hakielimu, 2010). Investing on teachers' education, promoting teacher qualifications and improving their skills can not only be through initial teacher education program but also from side to side combination of the initial teacher education and professional development (Saban, 2000).

Teachers are estimated to establish innovative role as a component of the logical improvement. Teachers professional development establish room for teacher to reconnoiter new innovations, new pedagogical technique, enhance their proformas and extend themselves both in professional sphere and individual skills (Hardman, F., 2013). It is essential to all educational stake holders and educational communities had better to understand the different hope of the teachers, the new administration characters as well as the duty \&and existing description of professional development, credit by all-inclusive community of the composite nature of the changes needed is the first step in creating necessary management practices that enables teachers fulfil their fundamental role in organized reforms (Mosha, 2009). Conversely schools are organizational and unorthodox, teachers are out-of-theway as one another and to some extent knowledgeable to fulfil their responsibility independently. School Management typically assist to promote teamwork. PD takes depend upon a deficit model in which an teachers who participate in professional program weights data and info to teachers who are expected to be incomplete and in requirement of external specialists to impart them up-to-date approaches of occupied with learners (Mbwambo 2015; Sambumbu, 2010, Essel, Badu, Owusu, Boateng and Albert 2009). 
PD needs systematic restructurings, shifting mutual structure of school standards besides performs inside teachers (Fullan, 2010). The changes procedure comprises four altitudes i.e. active initiation \& participation, pressure \& support, changes in performance, principles \& possession. Deprived of understanding the composite nature of changes and without creating professional development occasions used for teachers, school team member can end up espousing improvement after improvement without far-sighted slightly perfection in the advancement in educational objective (Akyeampong, 2013).

According to Mosha, (2016) different studies has testimony about the issue of teacher confident, it is believed that teachers are confident to their responsibilities but due to dynamicity in societal and educational spheres, there is dire need for extra tools to make them to fill the missing gape. Hence professional development program to teachers is inevitable (Mtana 2012, Taylor, Roth, Wilson, Stuhlsat, \& Tipton, 2017, Tecle, 2006). Professional development is essential tool in teaching profession (Muhammad \& Maka, 2015). Government, donor, and education stakeholders were responsible to provide and facilitate in-service training to teachers in public schools in Tanzania (Uwezo, 2018; Frenwick, 2011; Khamis \& Shammons 2007; Mwakabenga 2018; Mosha, 2009). Therefore, this study is intended to analyze the teacher's professional development by viewing school management practice in supporting teacher's professional development. There is inadequate training and guidance from principal to teachers (Akram et. al., 2020).

\section{Study Objective}

To analyze teacher professional development in Tanzania, by viewing school management practice on teachers professional development

\section{Research question}

To address the problem of the study researcher developed the following research questions:-

1. Does the school management plan and schedule the short term training programs and seminars for teacher professional development of teachers?

2. Does school management arrange formal mentoring program?

3. Does the school principle have the chance to plan specific objective of teachers' professional development?

4. Does school management encourage teachers to utilize the available resource center for improving their professional?

\section{LITERATURE REVIEW}

\section{Teacher professional development in the context}

Teacher Professional Development, is a regular process associated with modifications in facts, philosophies, and approaches among teachers and other education service sector workers towards improving educational result outcomes (Cooper, 2004) Teachers professional development refers to different presence form of in-service educational chances that are accessible to teachers through their school or school district(Komba and Nkubi, 2008) teachers' professional development refers to the procedure of refining the teachers' professional qualification to meet their duty standard inside and outside the formal learning environment. In this views appears to fit the essential of teacher professional development some forces are needed to support process and on among those force is the school management mechanism, MoEC (2010). In Tanzania context the articulation of Professional Development structure start at national level, by the central government providing policy frame work for practice some element decentralized to the local government level up to the school level, in the school level some element of professional development which are regular happening is like mentoring and coaching among the member of department.

\section{Implementation of teacher professional development in the context}

In Tanzania context Enactment of Teacher professional development is operating under Tanzania Institute of Education TIE. The institute inform teachers to the new curriculum and revised curriculum in the same line tie focusing on orienting educational stark holders to the matter relating to curriculum and professional development. TIE corroborating with other educational stake holders to provide professional development to teachers (MOEVT, 2017). TIE as the core actor of teachers Professional development they guided with national frame work for teacher professional development, the aim of national frame work is to promote coherent structure for implementing and practicing professional development in Tanzania (MOEVT, 2017).

\section{Practicing context/factor influence professional development}

Extension Needs: Is kind of professional development provided to senior teachers aimed to equip them with new skill and knowledge in order to improve their professional (Jahangir, Saheen \& Kazmi 2012). Refreshment Needs: here stress is only updating the past knowledge (Hacer, 2012). Conversional needs: in this kind of professional development teachers are trained to adapt the new role (Akhter et al 2011). Person oriented: here individual teacher put effort in engaging in different form of professional development for self-professional advancement or 
for self-need in improving school objective (Osamwonyi, 2016). Professional oriented: her professional development needed for advancing competence (Taylor, Roth, Wilson, Stuhlsat, \& Tipton, 2017). Job oriented: here professional development program is based on the specific role or immediately role of the teacher example the use of new learning tools (Akhter et al 2011). Teacher needs: here the professional development program depend on the teachers wish in expanding their skill example he can decide to go in training to learn more about specific subject matter. (Dorkeno, 2018) System and Instructional Needs: In this professional development may be arranged when there are implementation of the new roles in education organization and educational system (Jahangir, Saheen and Kazmi 2012). Curriculum implementation: here the professional development form. In this connection, professional development activities may be formalized to improve and reshape teachers knowledge in curriculum implementation (Evans, 2008) And other need can be School Improvement: here training can be arranged to update school staff on the matter relating school issues (Osamwonyi, 2016).

\section{School Management Practices}

In the study school management refereed as the organizational mechanism and applies that are intended at provided that backing to the teachers with the main goal quality advancing teachers in fulfilling their responsibility (Rogan and Fullan, 2017). School management should smoothen the practices for checking professional development of teachers. This practices might takings the formula of strategic and planning short term training and formal monitoring program, meeting detained at school level and at cluster level and utilization of teachers' resource centre (Abd-Kadir, 2013). According to Mosha, (2009) school management practices for teachers' professional development are fundamental aimed at indorsing teacher's development and great superiority education. Because teachers are the part and parcel of teaching and learning process where changes take place hence teachers fulfilling their responsibility effective this is because teachers are closest to the school and classroom where reforms will be enacted (Blasé and Blasé, 2007). School management practices also can be defined as role of school managers to enhance school atmosphere by utilizing inside and outside resource to promote better teaching and learning process (Komba, 2016).

\section{Role of school management to teachers' professional development}

For the assurance of teachers to participate in professional development program School management advised to offer an ample time to teachers in order for them to be free to participate in professional development program and to practice what they learn in the program hence improve of teachers professional (Abdou, 2017; Dervin, 2018). Once the workers get the chance to participate in several form of professional development activity, they fill belongings of the organization, feel the supportiveness of the organization this may encourage workers to work more, being faithfully to the organizational goal and hence low intention to quit their job (Lala et al, 2012) to some extent not all organizational can offer their employee professional development opportunity, once organizational offer such opportunity in turn can translate employee positive attitude and feeling as the part and parcel of the organization hence employee work with passion which may lead better organizational (Taylor, Roth, Wilson, Stuhlsat, and Tipton, 2017).

Principals are responsible to deal with all challenges occurring in schools, teachers professional development and advancement is an important area of them (Parveen et. al., 2021). Furthermore, principals can support teachers energies by providing information and guide them to different professional development opportunity inside and outside to the school compound (URT 2015). Also they can insure staff development which are provided is linked to the school objective and teachers professional advancement, also school principle can act as the supervisor by arranging time to evaluate what teachers learn from the professional development program by observing how teacher implement it in the school area and in classroom activities (Komba 2012). What school principle observe from teachers after professional development program is very important, school principle can use those feedback to evaluate teachers achievement and to encourage them to perform more or to arrange other staff development activities to make them to improve more (Tsotetsi, 2012). Without presence of clear evidence teachers can act negatively when they asked to perform what they learn from professional development program therefore in schools principles should have clear mechanism on how to make teachers to provide professional development feedback to the other staff (Nzarirwehi, and Atuhumuze, 2019). A good and wealth feedback of professional development program can be observed from classroom formative because to some extent teachers they appreciate evidence which they gather them self so school management encouraged to provide room for classroom assessment (Nishimura, 2014 Dervin, 2018, 0'Dwyer and Atll, 2015). Though changes is not a simple activities and not all staff can be lead to accept changes its need and extra energy and cooperation between school management and staff teachers(Okiror, Hayward, and Winterbottom, 2017).

School management are like other organization management, usually staff they have trends to trust there management and to some extent staff can act positive to please the managements so teachers can have more positive perception on the evaluation done by their school management than from other managerial act, in the some line school principle can analyses specific area which they need teaches to improve and arrange some staff development program and encourage teachers to attend for better school improvement (Morales, 2016, Tuncel, and 
Çobanoğlu, 2018). As soon as the school management making assessment of any professional development program which their teachers attend it's may bring meaningful to staff and can encourage their professional growth (Okiror, Hayward and Winterbottom, 2017).

Due to societal diversity every school they have their specific need school management advised decide on their specific objective of the professional development programs, it achievement can bring positive changes to the learning and teaching process to the particular area (Popova, Evan, and Arancibia, 2016, Li, Y and Dervin, 2018, Safi. 2015). Deciding on the specific objective and needed knowledge as whole depend on the degree of accountability from both principal and school management in ensuring student learning goal are achieved, achievement of student leaning should be the core of strategic planning and resource management proper allocation of the available resource in creating professional development management (MoE, 2009). In addition to that school management are expected to collaborate with other educational administrative and educational stake holders, educational professionals to bring more professional growth to their staff (Owen, 2014; Vangrieken et al., 2017; Wang, 2016).

Along with other features, assert that supportive leadership such as the establishment of structures for friendly communication, socialization, support, and empowerment for newly and experienced teachers is essential in ensuring the success of teacher professional development program (Owen 2014 Sezer, Karaoğlan-Yılmaz, and Yllmaz, 2017, Lee, 2018). Moreover, supportive leadership ensures that teachers remain committed to their professional learning goals and values. In their analysis of effective features of professional learning, Vangrieken et al. (2017) highlighted the need for providing leadership support in teacher professional learning at the school level, a supportive leadership is also pivotal in improving teachers' senses of autonomy and collaborative learning. The success of school management in professional development programs depends on the principal creating space for teachers to share good practices and content knowledge (Khamis and Shammons, 2007, Mwakabenga 2018).

\section{THEORETICAL FRAMEWORK}

\section{Adult learning theory}

The theory was based on the ways which adult can learn, Theory based on andragogy, it is founded with Alexander Kapp, a German educator, in 1833, and advanced into a philosophy of adult education by American guru, Malcolm Knowles. Originating from the Greek words meaning 'man-leading', andragogy involve of knowledge plans concentrated on adults and main principally defined as the "the art and science of helping adults learn" (Tracey and Mandel, 2012). The main idea of theory is to differentiate adult learning from children learning.

The doctrines of the theory include:

- Adults restored learning from their past knowledge

- Adults prefer a realistic approach which can be applied in solving specific issue.

- Adults wish to learn things which can cause observable changes.

- Adults require to be involved in matters relating to their progress (Mwakabenga 2018, Milhem, W, Abushamsieh, K \& Aróstegui, M, 2014).

Consequently, teachers like other adult prefer to be included in structuring and evaluation process of their learning and to be part on the important decision why particular learning is important to them; that means teacher as matured people does not participate in learning as the empty vacuum they participate in learning depending on their experience, thus experience can include their past achievement and mistake and all of this act as the basis for the learning activities. Different teachers' task and responsibility can encourage their spirit in learning (Kennedy, 2005, Alabi, and Ige, 2014).

Teachers like any adult, they need critical factor which will force them learn. Those factors supposed to be focused in brought some changes to the existing situation. Professional development as the kind of adult learning supposed to be problem centered and changes actor. It can associate changes in attitude, believes and healing to overcome embarrassment (Brookfield, 2003; Bautista 2015). If the professional development will be well systemized to cutter the need of teachers professional need and personal need to allow teachers as the adult learner to have inputs and autonomy to their professional development program. Teachers will reduce fair to participate in learning be happier and fill the belonging with their provided professional development program and they can be motivated to participate in those professional development program (Tunce and Çobanoğlu, 2018).

To some extent, adult learning is not involuntary activity. It needs a support from the system in different issues including, coaching, mentoring, material for learning, time for participating in learning, and some time need financial support etc. In this situation, school management can play a role by providing support with teachers professional development programs which are within their mandate (Sedega, Mishiwo, Seddoh, and Dorkenoo, 2018). Professional issue and pressure existing between teachers and school management play important role for school development teachers are important part in school. Lacking of well-organized school management can hinder the school improvement and good school management (UNESC0, 2003, Fullan, 2010, Balta, and Duru, 2015). 


\section{RESEARCH METHODOLOGY}

\section{Research design}

The study intended to investigate school management practice on teachers' professional development. Descriptive survey was used. The study help to back upto the individualities that exist in population, nevertheless it's not examine cause and effect relationship. The reason to use this design is the need for gathering of accurate information about the situation (Kothari, 2014).

\section{Data Collection Method}

This study included both primary and secondary data. Primary data source includes, questionnaires, interview, focus group discussions with teachers and secondary data includes journal, and different professional development program reported in the context (Komba, 2016).

\section{Data Analysis}

Data analysis based on both qualitative data and quantitative data, qualitative data collected by using interview, and focus group discussion with teachers examined and classified according to pattern and content. Quantitative data gathered through questionnaire were analyzed by using frequency and percentage. Data were analyzed to get accurate information about the study.

\section{Presentation of the Findings}

Researcher presented the finding with regard of the research question in order to reveal the insight view from the data collected to provide the knowledge on the management practices for teacher professional development.

\section{Planning and scheduling short term training program and seminars}

Table 1. Planning and scheduling short term training program and seminars

\begin{tabular}{lrr}
\hline & Frequency & Percent \\
\hline Strongly Disagree & 0 & 00.0 \\
Disagree & 3 & 5.0 \\
Neutral & 6 & 10.0 \\
Agree & 30 & 50.0 \\
Strongly Disagree & 21 & 35.0 \\
Total & 60 & 100.0 \\
Source, Research data (2021) & &
\end{tabular}

Result indicate $85 \%$ of School management support Teacher Professional Development by giving them permission to participate in different professional development program. School management creates good relation with colleges, teaching staff and finding experts from outside the school to share experience with teachers. While $5 \%$ of the respondents disagreed with the statement and lastly $10 \%$ of respondents were neutral. Head teachers are supporting Teacher Professional Development by allowing teachers to participate, seminars, and sensitizing teachers to take the initiative of upgrading themselves (MoEC 2015; Sumra et al 2010). According to Tecle, et al (2006) school principle involved in planning and implementing Teacher Professional Development by identify the topics and issues to be discussed.

\section{Formal Mentoring Program}

Table 2. Formal Mentoring Program

\begin{tabular}{lll}
\hline & Frequency & Percent \\
\hline Strongly Disagree & 5 & 8.3 \\
Disagree & 7 & 11.6 \\
Neutral & 6 & 10.0 \\
Agree & 28 & 46.3 \\
Strongly Disagree & 13 & 21.7 \\
Total & 60 & 100.0 \\
Source; Research data (2021) & & \\
\hline
\end{tabular}

Respondents were asked on how managers work best on the established mentoring program and $68 \%$ of the respondents agreed with the statement that head teachers act as inspectors and coordinators, played a significant role in in ensuring that teachers are mentored and their professional is improved. While 19.3\% disagreed with the statement (Mazana et al, 2015). (Komba, 2016) pointed out that school management play an important role in helping teachers to develop professionally, encourage teachers within the department to mentor each other. According to the teachers, school principals provide advice about the advantages of going for professional development courses; they also give advice on how to teach effectively through proper preparation of schemes of work, lesson plans and how to conduct a class effectively. 


\section{Utilization of Teacher Resources Centre}

In this context researcher seek data on how school management encourage teachers professional and utilization of available teacher resource centre as the part and parcel for teachers professional development, the respondent mention that school management support them to utilize the teachers resource centre by structuring the time table which teachers who need to go to those learning centre get an ample time to go and learning, and school management enacted by law which energize teachers to attend in those learning centre as well to take care the resource centre also respondent testimony that" The school management insists that our staff members to get chance to go to cluster to utilize resource to upgrade knowledge in order to get more knowledge and skills (Komba, 2016, Nzarirwehi, \& Atuhumuze ,Makerere 2019).

\section{School management decision on specific objective of the professional development program}

School management have the role to make decision on the specify body of knowledge which they wish their teachers to acquire and they supposed to make sure the implication and policy well described in the school area (Popova, Evan, and Arancibia, 2016). In other words school management supposed to decide what acquire and to provide full support for teachers to get that knowledge and to implement it in school is necessary for teachers to implement ((Li, Y and Dervin, 2018, Safi. 2015). The study reveals that $99 \%$ school management does not have the autonomy to choose the specific objective of the program this because most of the programs are donna funded therefore donnas decide themselves the input of the program.

\section{DISCUSSION}

The focus of the study was to get actual information on the analysis of teacher's professional development in Tanzania context view point school management practice. The study has analyzed the management practices that affect teachers' professional development. The analysis revealed that management practices reviewed under this study including utilization of teacher's resources, selection of specific objectives of professional development programs, planning and scheduling short term training program, seminars and introducing formal mentoring programs. This is in line with (Blasé and Blasé, 2007) as pointed out that school manager supposed to use some management practices to provide room to teachers to improve their professional.

The study has showed that mentoring program introduced within the school enable teachers to develop their professional and provide extra skills in helping the student to improve their performance. Mbwambo, (2015) teachers requires mentoring professionals to mentor them new approaches to deal with the students. Furthermore the study has revealed on school meeting participation which enable teachers to make decision and share different ideas that completely enable them to develop their teaching professional (Komba, 2016). The finding indicate on $90 \%$ school management does not have the autonomy to plan specific objective for the professional development program even though literatures emphasize the importance of school management to be involved in planning for specific objective for professional development programs.

\section{CONCLUSION}

Through this study school management play important role in teachers professional development; school management encouraged to plan and scheduling short term training programs and seminars, formal mentoring program, meeting held at school level and encourage teachers on the effective utilization of teachers learning resource as well the study suggest the government to increase autonomy to school management to have the power to choose specific objective to teachers professional development.

\section{RECOMMENDATION OF THE STUDY}

From the finding, it is recommended that school management should make sure they create good atmosphere for Teacher Professional Development within their school by incorporating managing practices that will further enable teachers to be directly involved in improving their professional development program to perform their obligation rationally and effectively. Some of the management practices studied in this study include planning and scheduling short term training program and seminars, formal mentoring program and coaching at school level utilization of teacher resources centre and selection of specific objective, also from the finding we can recommend that professional development policy should provide a clear autonomy to school management in selecting specific objective of the professional development program which match with the need of their school.

\section{REFERENCES}

Abd-Kadir, J., \& Hardman, F. (2013). Reforming teacher education in East Africa: the importance of socio-cultural context. In Researching Cultures of Learning (pp. 80-94). Palgrave Macmillan, London.

Akram, H., Yingxiu Yang, N. A., \& Aslam, S. (2020). Factors Contributing Low English Language Literacy in Rural Primary Schools of Karachi, Pakistan. International Journal of English Linguistics, 10(6).

Akyeampong, K., Lussier, K., Pryor, J., \& Westbrook, J. (2013). Improving teaching and learning of basic maths and reading in Africa: Does teacher preparation count?. International journal of educational development, 33(3), 272-282. 
Alabi, F. O., \& Ige, A. M. (2014). Issues in in-service education provision for teachers in Nigeria. The way forward in this decade and beyond. International Journal of Humanities, Social Sciences and Education (IJHSSE), 1(12), 126-132.

Beare, H., Caldwell, B. and Millikan, R. (2010); 'Leadership'; in: Preedy, M. (ed); Managing the Effective School; London: Chapman

Blase, J., \& Blase, J. (1999). Principals' instructional leadership and teacher development: Teachers' perspectives. Educational administration quarterly, 35(3), 349-378.

Fenwick, T. J. (2001). Teacher supervision through professional growth plans: Balancing contradictions and opening possibilities. Educational Administration Quarterly, 37(3), 401-424.

FULLAN, M. (2010, 4th edn.); The New Meaning of Educational Change; London: Routledge Falmer

GOVERNMENT OF TANZANIA (1997); Whole School Development Planning: A Manual for Primary Schools in Tanzania; Dar es Salaam: Ministry of Education and Culture

Li, Y., \& Dervin, F. (2018). Continuing professional development of teachers in Finland. Springer.

Malekela, G. A. (2004). Report of the assessment on the impact of participation of head teachers in the three month certificate course in management skills on their schools. Report submitted to the Agency for the Development of Education Management (ADEM), Bagamoyo.

Mbwambo, E. E. (2005). Teacher Motivation and Student Academic performance in secondary schools. Unpublished MA (Education) Dissertation: University of Dar es Salaam.

MoEC (2010) Basic Statistics in Education 1995-2016, Dar es Salaam.

MoEC (2010) Tanzania Education Status Report, Dar es Salaam

MoEC (2010). Primary Education Development Programme, Dar es Salaam.

MoEC (2015) Tanzania Education Status Report, Dar es Salaam

Mosha (2009). Capacity of school management for teacher professional development in Tanzania. A Key Note Address. Delivered at a workshop on the Role of universities in promoting basic education in Tanzania, held at the Millenium Towers Hotel, Dar es Salaam, Tanzania, and Friday May 19.

Mwakabenga, R. J. (2018). Developing teacher-led professional learning in a Tanzanian secondary school: a thesis presented in partial fulfilment of the requirements for the degree of Doctor of Philosophy in Education at Massey University, Manawatū, New Zealand (Doctoral dissertation, Massey University).

Nzarirwehi, J., \& Atuhumuze, F. (2019). In-Service Teacher Training and Professional Development of Primary School Teachers in Uganda. IAFOR Journal of Education, 7(1), 19-36.

Parveen, K., Phuc, T. Q. B., Shafiq, M., \& Wei, T. X. (2021). Identifying the administrative challenges encountered by the principals in low-performing public secondary schools of Faisalabad District, Pakistan. International Journal of Humanities and Innovation (IJHI), 4(1), 5-16.

Rajani, R., \& Sumra, S. (2003). Is extra funding for primary education making a difference? Conceptual and measurement challenges (No. 3). HakiElimu Working Paper Series.

Rogan J (2016). Professional development: Implications for developing countries. In Kalafunja O-saki, Ken Hosea and Wout Ottevanger, Reforming science and mathematics education in sub-saharan Africa. Obstacles and opportunities, pp.155-170.

Rogan J (2017). Professional development: Implications for developing countries. Reforming science and mathematics education Tanzania. Obstacles and opportunities, pp.155-170.

Rogan, J. M., \& Grayson, D. J. (2003). Towards a theory of curriculum implementation with particular reference to science education in developing countries. International journal of science education, 25(10), 1171-1204.

Sedega, B.C ,Mishiwo, M , Seddoh, J,E \& Dorkenoo, A,B (2018) Perception of teachers on the effectiveness of inservice education and training at the basic schools in akatsi district of Ghana; British Journal of Education, 6 , (12), 50-68.

Tecle, T. (2006). The potential of professional development scenario for supporting biology teachers in Eritrea. Enschede: Print Partners IPS Kamp.

URT/MoEC/JICA (2005). The Study on school mapping and micro-planning in education in the United Republic of Tanzania. Final Report Summary. PADECO Co. Ltd. 
Publisher's note: Science Impact Publishers remain neutral with regard to jurisdictional claims in published maps and institutional affiliations.

Open Access This article is licensed under a Creative Commons Attribution 4.0 International License, which permits use, sharing, adaptation, distribution and reproduction in any medium or format, as long as you give appropriate credit to the original author(s) and the source, provide a link to the Creative Commons license and indicate if changes were made. The images or other third-party material in this article are included in the article's Creative Commons license, unless indicated otherwise in a credit line to the material. If material is not included in the article's Creative Commons license and your intended use is not permitted by statutory regulation or exceeds the permitted use, you will need to obtain permission directly from the copyright holder. To view a copy of this license, visit https://creativecommons.org/licenses/by/4.0/.

(C) The Author(s) 2020 